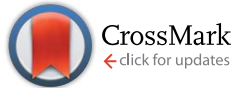

Cite this: Chem. Sci., 2016, 7, 4220

\title{
Cation-mediated optical resolution and anticancer activity of chiral polyoxometalates built from entirely achiral building blocks $\uparrow$
}

\author{
Zhi-Ming Zhang, $\star^{\mathrm{abc}}$ Xiaopin Duan, $\ddagger^{\mathrm{b}}$ Shuang Yao, ${ }^{\mathrm{b}}$ Zhishu Wang, ${ }^{\mathrm{a}}$ Zekai Lin, ${ }^{\mathrm{b}}$ \\ Yang-Guang Li, ${ }^{a}$ La-Sheng Long, ${ }^{c}$ En-Bo Wang*a and Wenbin Lin ${ }^{\star b c}$
}

We report the crystallization of homochiral polyoxometalate (POM) macroanions $\left\{\mathrm{CoSb}_{6} \mathrm{O}_{4}\left(\mathrm{H}_{2} \mathrm{O}\right)_{3}\left[\mathrm{Co}(\mathrm{hmta}) \mathrm{SbW}_{8} \mathrm{O}_{31}\right]_{3}\right\}^{15-}(1, \mathrm{hmta}=$ hexamethylenetetramine $)$ via the counter cationmediated chiral symmetry breaking and asymmetric autocatalytic processes. In the presence of low $\mathrm{Co}^{2+}$ concentrations both $\Delta$ - and $\Lambda$-enantiomers of 1 formed in the reaction, crystallizing into the racemic crystal rac-1. At a high $\mathrm{Co}^{2+}$ concentration, the polyoxoanion enantiomers showed a high level of chiral recognition via $\mathrm{H}$-bonding interactions to crystallize into enantiopure crystals of $\Delta$ - or $\Lambda$ $\left[\mathrm{Co}\left(\mathrm{H}_{2} \mathrm{O}\right)_{6}\left\{\mathrm{CoSb}_{6} \mathrm{O}_{4}\left(\mathrm{H}_{2} \mathrm{O}\right)_{3}\left[\mathrm{Co}(\mathrm{hmta}) \mathrm{SbW}_{8} \mathrm{O}_{31} 1\right]_{3}\right\}\right]^{13-}$. During crystallization, a microscale symmetrybreaking event and a nonlinear asymmetric autocatalysis process make the enantiomers crystallize in different batches, which provides an opportunity to isolate the homochiral bulk materials. The defined structures of the racemic and homochiral crystals thus provide a molecular-level illustration that $\mathrm{H}$ bonding interactions are responsible for such high-level chiral recognition, in a process similar to the supramolecular chirality frequently observed in biology. These POM macroanions showed a high cytotoxicity against various cancer cells, particularly ovarian cancer cells. The antitumor activity of these compounds resulted at least in part from the activation of the apoptotic pathways, as shown by the flow cytometry, Annexin V staining, DNA ladder, and TUNEL assay, likely by blocking the cell cycle and complexing with proteins in cells. The POM macroanions reported herein provide promising and novel

antitumor agents for the potential treatment of various cancers.

Received 17th November 2015 Accepted 9th March 2016

DOI: $10.1039 / \mathrm{c} 5 \mathrm{sc} 04408 \mathrm{a}$

www.rsc.org/chemicalscience

\section{Introduction}

Chirality plays a critical role in biology and is also important for the functions of many materials. ${ }^{1-3}$ In biological systems, homochirality is an essential feature of basic building blocks, such as amino acids and sugars, which are distinctly left- and right-handed. ${ }^{4,5}$ Although the origin of homochirality is firmly established in biological systems, the spontaneous assembly of enantiopure materials from achiral precursors still represents a great challenge to chemists and material scientists. ${ }^{6,7}$

\footnotetext{
${ }^{a}$ Key Laboratory of Polyoxometalate Science of Ministry of Education, Faculty of Chemistry, Northeast Normal University, Ren Min Street No. 5268, Changchun, Jilin 130024, P. R. China. E-mail: wangeb889@nenu.edu.cn

${ }^{b}$ Department of Chemistry, University of Chicago, 929 E. 57th Street, Chicago, Illinois 60637, USA. E-mail: wenbinlin@uchicago.edu

${ }^{c}$ Collaborative Innovation Center of Chemistry for Energy Materials, Xiamen University, Xiamen $361005, P$. R. China

$\dagger$ Electronic supplementary information (ESI) available: Supplementary structural figures, IR, TG, CD, ESI and antitumor results. CCDC 1431324 and 827684. For ESI and crystallographic data in CIF or other electronic format see DOI: 10.1039/c5sc04408a

$\$$ The authors contributed equally to this work.
}

Polyoxometalates (POMs), a class of metal-oxo clusters with oxygen-rich surfaces, have been extensively explored for applications in biology, magnetism, catalysis, and material science. ${ }^{8}$ The introduction of chirality into POMs or POMorganic hybrid compounds can endow further functionality for potential applications in nonlinear optics, enantioselective catalysis, chiral medicine, and chiral magnetism. ${ }^{9-14}$ Chiral ligands are typically used as structure-directing agents to facilitate the synthesis of chiral POM materials. ${ }^{11-13}$ A more versatile approach towards such a synthesis would use completely achiral precursors to construct chiral POM skeletons via bond length alteration, structure distortion, formation of lacunae, replacement with other metals, or decorating with organic ligands to remove the inversion and/ or mirror symmetry in POMs. ${ }^{\mathbf{9 1 4}}$ However, bulk materials generally contain a racemic mixture of chiral POMs or POM materials. Achieving homochirality from totally achiral precursors is still a significant challenge in the laboratory. ${ }^{15}$

Among numerous potential applications, POMs have been reported to possess promising antibacterial, antiviral, and anticancer activities, which may open the way toward new and affordable therapeutic strategies for various human diseases. ${ }^{\mathbf{1 6}}$ 
Several POMs have been recognized as potential antitumor agents; ${ }^{17}$ in particular, $\left[\mathrm{NH}_{3} \mathrm{Pr}^{\mathrm{i}}\right]_{6}\left[\mathrm{Mo}_{7} \mathrm{O}_{24}\right] \cdot 3 \mathrm{H}_{2} \mathrm{O}$ (PM-8) was found to exhibit antitumor activity against multiple cancers in vitro and in vivo. ${ }^{18}$

We observed that chiral recognition between POM macroanions and $\mathrm{Co}\left(\mathrm{H}_{2} \mathrm{O}\right)_{6}{ }^{2+}$ counter cations via hydrogen bonds led to chiral symmetry breaking, affording homochiral crystalline materials. These POM macroanions also exhibited potent antitumor activities against various human cancer cells, resulting from the activation of apoptotic pathways by blocking the cell cycle and complexing with proteins in cells.

\section{Results and discussion}

\section{Synthesis}

The chiral POM-based molecular capsule $\left\{\operatorname{CoSb}_{6} \mathrm{O}_{4}\left(\mathrm{H}_{2} \mathrm{O}\right)_{3^{-}}\right.$ $\left.\left[\mathrm{Co}(\mathrm{hmta}) \mathrm{SbW}_{8} \mathrm{O}_{31}\right]_{3}\right\}^{15-}$ (hmta $=$ hexamethylenetetramine) was assembled by treating the achiral polyoxoanion $\left[\mathrm{NaSb}_{9} \mathrm{~W}_{21}{ }^{-}\right.$ $\left.\mathrm{O}_{86}\right]^{18-}\left(\left\{\mathrm{Sb}_{9} \mathrm{~W}_{21}\right\}\right)$ with $\mathrm{Co}^{2+}$ ions and hmta molecules in aqueous solution. In the synthesis, the trimeric $\left\{\mathrm{Sb}_{9} \mathrm{~W}_{21}\right\}$ ion with $C_{3 \mathrm{~h}}$ symmetry (Fig. S1a $\uparrow$ ), comprising three $\left\{\mathrm{SbW}_{7} \mathrm{O}_{24}\right\}\left(\left\{\mathrm{SbW}_{7}\right\}\right)$ units surrounding a central $\left\{\mathrm{NaSb}_{6} \mathrm{O}_{14}\right\}$ core, was used as the starting material. The resulting POM macroanion contains three $[\beta-$ $\left.\mathrm{Co}(\mathrm{hmta}) \mathrm{SbW}_{8} \mathrm{O}_{32}\right]$ units surrounding a central $\left\{\mathrm{CoSb}_{6} \mathrm{O}_{4}\left(\mathrm{H}_{2} \mathrm{O}\right)_{3}\right\}$ core, affording a trimeric capsule-like molecule with $C_{3}$ symmetry. Both $\left(\mathrm{NH}_{4}\right)_{8}\left[\Delta-\mathrm{Co}\left(\mathrm{H}_{2} \mathrm{O}\right)_{6}\left\{\mathrm{CoSb}_{6} \mathrm{O}_{4}\left(\mathrm{H}_{2} \mathrm{O}\right)_{3}[\mathrm{Co}(\mathrm{hmta})\right.\right.$ $\left.\left.\left.\mathrm{SbW}_{8} \mathrm{O}_{31}\right]_{3}\right\}\right] \cdot(\mathrm{Hhmta})_{5} \cdot 29 \mathrm{H}_{2} \mathrm{O} \quad(\Delta-2)$ and $\left(\mathrm{NH}_{4}\right)_{8}\left[\Lambda-\mathrm{Co}\left(\mathrm{H}_{2} \mathrm{O}\right)_{6}-\right.$ $\left.\left\{\mathrm{CoSb}_{6} \mathrm{O}_{4}\left(\mathrm{H}_{2} \mathrm{O}\right)_{3}\left[\mathrm{Co}(\mathrm{hmta}) \mathrm{SbW}_{8} \mathrm{O}_{31}\right]_{3}\right\}\right] \cdot(\mathrm{Hhmta})_{5} \cdot 29 \mathrm{H}_{2} \mathrm{O} \quad(\Lambda-2)$ enantiomers formed during the assembly process, resulting in a racemic solution that crystallized into racemic crystals of $\left(\mathrm{NH}_{4}\right)_{9}\left\{\mathrm{CoSb}_{6} \mathrm{O}_{4}\left(\mathrm{H}_{2} \mathrm{O}\right)_{3}\left[\mathrm{Co}(\mathrm{hmta}) \mathrm{SbW}_{8} \mathrm{O}_{31}\right]_{3}\right\} \cdot \mathrm{Cl} \cdot(\mathrm{Hhmta})_{7} \cdot 33 \mathrm{H}_{2}-$ $\mathrm{O}(\mathbf{1})$ at low $\mathrm{Co}^{2+}$ concentrations (ca. $46 \mathrm{mM}$ ).

Crucial to the reaction was the $\mathrm{pH}$ value, which was in the 7.5-8.5 range at the beginning of the reaction and decreased to 7.0-7.6 after two hours. The hmta molecules not only acted as the coordinating ligands but also served as a base to control the $\mathrm{pH}$ value of the reaction system. If other bases such as $\mathrm{NH}_{3} \cdot \mathrm{H}_{2} \mathrm{O}, \mathrm{NaOH}$, and $\mathrm{KOH}$ were used to replace hmta in the reaction, the capsule-type POMs could not be isolated. In the synthesis, by increasing the $\mathrm{Co}^{2+}$ concentration, the capsules underwent a completely enantioselective self-resolution; they self-assembled into individual single crystals composed of the same enantiomers but did not form racemic single crystals comprising opposite enantiomers. Strikingly, the homochiral crystallization process led to the same handedness of individual crystals in each batch, affording the homochiral bulk materials $\left[\Delta-\mathrm{Co}\left(\mathrm{H}_{2} \mathrm{O}\right)_{6}\left\{\mathrm{CoSb}_{6} \mathrm{O}_{4}\left(\mathrm{H}_{2} \mathrm{O}\right)_{3}\left[\mathrm{Co}(\mathrm{hmta}) \mathrm{SbW}_{8} \mathrm{O}_{31}\right]_{3}\right\}\right]^{13-}(\Delta-2)$ and $\left[\Lambda-\mathrm{Co}\left(\mathrm{H}_{2} \mathrm{O}\right)_{6}\left\{\mathrm{CoSb}_{6} \mathrm{O}_{4}\left(\mathrm{H}_{2} \mathrm{O}\right)_{3}\left[\mathrm{Co}(\mathrm{hmta}) \mathrm{SbW}_{8} \mathrm{O}_{31}\right]_{3}\right\}\right]^{13-}(\Lambda-2)$.

\section{Structure}

Compound 1 crystallizes in the achiral monoclinic $P 2_{1} / c$ space group, whereas compound 2 crystallizes in the cubic chiral space group $P 2_{1} 3$. Single-crystal X-ray diffraction analyses revealed that compounds 1 and 2 both contain a screw propeller-like cluster $\left\{\mathrm{CoSb}_{6} \mathrm{O}_{4}\left(\mathrm{H}_{2} \mathrm{O}\right)_{3}\left[\beta-\mathrm{Co}(\mathrm{hmta}) \mathrm{SbW}_{8} \mathrm{O}_{31}\right]_{3}\right\}^{15-}$, which is built from a trimeric capsule-type polyoxotungstate and three hmta ligands
(Fig. 1 and S1b $\dagger$ ). The capsule-type POM $\left\{\mathrm{CoSb}_{6} \mathrm{O}_{4}\left(\mathrm{H}_{2} \mathrm{O}\right)_{3}[\beta-\right.$ $\left.\left.\mathrm{Co}(\mathrm{hmta}) \mathrm{SbW}_{8} \mathrm{O}_{31}\right]_{3}\right\}$ consists of a cryptate polyoxoanion $\left\{\mathrm{Sb}_{6} \mathrm{O}_{4}\left(\beta-\mathrm{SbW}_{8} \mathrm{CoO}_{31}\right)_{3}\right\}$ that is composed of three tetravacant tungstoantimonates $\left[\beta-\mathrm{SbW}_{8} \mathrm{O}_{31}\right]$ (Fig. $\mathrm{S} 2$ and $\mathrm{S} 3 \uparrow$ ). In the POM family, trivacant Keggin tungstoantimonate $\left\{\mathrm{SbW}_{9} \mathrm{O}_{33}\right\}$ is a common structural motif that is used to construct other POM compounds including dimeric systems and 1-D and 2-D polymeric structures. ${ }^{19}$ The pentavacant $\left\{\mathrm{SbW}_{7}\right\}$ unit is also observed in the cryptate polyoxoanion $\left\{\mathrm{Sb}_{9} \mathrm{~W}_{21}\right\} .{ }^{20}$ However, trimeric capsule-type tungstoantimonates based on tetravacant $\left[\beta-\mathrm{SbW}_{8} \mathrm{O}_{31}\right]$ units in $\mathbf{1}$ and $\mathbf{2}$ have not been reported in the literature.

Each tetravacant $\left[\beta-\mathrm{SbW}_{8} \mathrm{O}_{31}\right]$ unit captures one $\mathrm{Co}^{2+}$ ion to form a mono-cobalt-substituted trivacant Keggin-type polyoxoanion $\left[\beta-\mathrm{SbW}_{8} \mathrm{CoO}_{31}\right]$, which is fused together by $\mathrm{W}-\mathrm{O}-\mathrm{Co}$ bonds to afford a triangular polyoxoanion $\left[\beta-\mathrm{SbW}_{8} \mathrm{CoO}_{31}\right]_{3}$ (Fig. S4 and S5 $\dagger$ ). The triangular polyoxoanion $\left[\beta-\mathrm{SbW}_{8} \mathrm{CoO}_{31}\right]_{3}$ combines with six $\mathrm{Sb}^{3+}$ ions to form a cryptate-type polyoxoanion $\left\{\mathrm{Sb}_{6} \mathrm{O}_{4}\left(\beta-\mathrm{SbW}_{8} \mathrm{CoO}_{31}\right)_{3}\right\}$. In the cryptate-type polyoxoanion, there are nine $\mathrm{Sb}^{3+}$ centers in total, which can be divided into three groups according to their positions and functions (Fig. S2 and $\mathrm{S} 6 \dagger$ ). The first three $\mathrm{Sb}^{3+}$ ions reside at the central sites of the $\left[\beta-\mathrm{SbW}_{8} \mathrm{O}_{31}\right]$ units to form the tetravacant $\beta$ Keggin structure $\left[\beta-\mathrm{SbW}_{8} \mathrm{O}_{31}\right]$; the second three $\mathrm{Sb}^{3+}$ ions locate at one side of the cryptate-type polyoxoanion $\left[\beta-\mathrm{SbW}_{8} \mathrm{CoO}_{31}\right]_{3}$, and are fused together by a $\mu_{3}$-oxo atom to form the triangular bottom of the polyoxoanion cryptate (Fig. S6c $\dagger$ ); the last three $\mathrm{Sb}^{3+}$ ions form a triangular $\left\{\mathrm{Sb}_{3}\right\}$ group that caps on the cryptate-type polyoxoanion (Fig. S6b $\dagger$ ). Furthermore, the cryptatetype polyoxoanion captures one $\mathrm{Co}^{2+}$ to afford a nanosized molecular capsule. The molecular capsule is further functionalized by three hmta ligands, resulting in the screw propellerlike cluster $\left\{\mathrm{CoSb}_{6} \mathrm{O}_{4}\left(\mathrm{H}_{2} \mathrm{O}\right)_{3}\left[\beta-\mathrm{Co}(\mathrm{hmta}) \mathrm{SbW}_{8} \mathrm{O}_{32}\right]_{3}\right\}$ (Fig. 1 and S1b $\dagger$ ), which exhibits a 3-fold rotational axis corresponding to the $C_{3}$ symmetry. In the crystallization process, the triangular cluster compounds form highly transparent and well-shaped single crystals, showing rhomboid and tetrahedral shapes for $\mathbf{1}$ and 2, respectively (Fig. 2). The bulk achiral and chiral crystals can be identified based on their shapes with the naked eye.

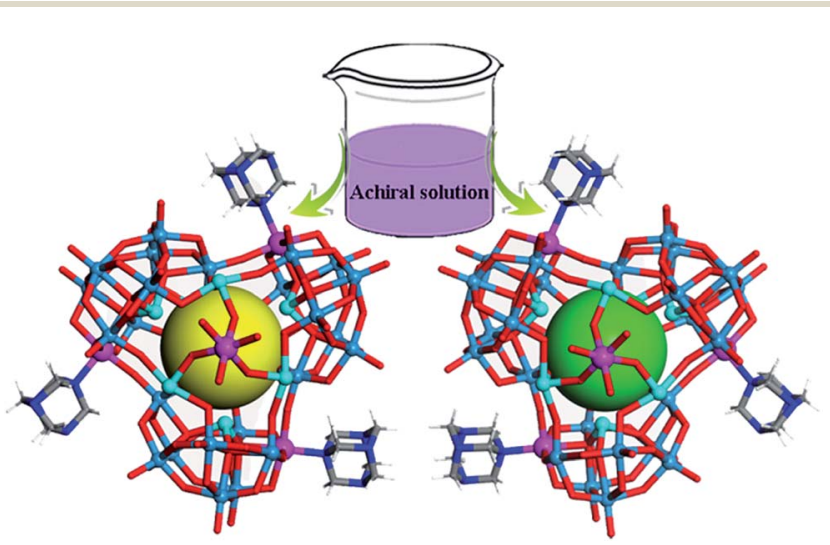

Fig. 1 Schematic showing the spontaneous resolution of enantiopure molecular capsules from achiral building blocks. W, light blue; Sb, cyan; Co, purple; N, blue; O, red; C, light grey; $\mathrm{H}$, white. 


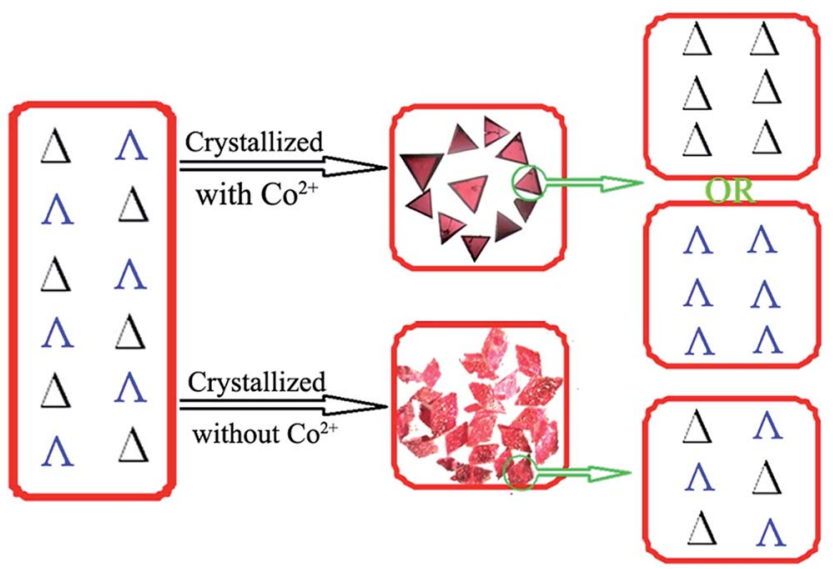

Fig. 2 Schematic view of the chiral recognition during crystallization of the racemic solution to the homochiral crystal with $\mathrm{Co}^{2+}$-mediated interactions (top), or to the racemic crystal (bottom).

\section{Enantioselective crystallization}

The chiral molecular capsule was assembled from achiral building blocks in aqueous solution. Circular dichroism (CD) studies confirmed that both enantiomers formed in the reaction. Single crystal X-ray diffraction analysis revealed that the enantiomers displayed a complete enantioselective self-resolution with the assistance of $\mathrm{Co}^{2+}$ ions during the crystallization process (Fig. 2). The formation of heteromeric assemblies was also observed without co-crystallization of the $\mathrm{Co}^{2+}$ counter cation (Fig. 3), while enantiopure crystals of $\Delta$ - or $\Lambda-\left[\mathrm{Co}\left(\mathrm{H}_{2} \mathrm{O}\right)_{6}\left\{\mathrm{CoSb}_{6}\right.\right.$ $\left.\left.\mathrm{O}_{4}\left(\mathrm{H}_{2} \mathrm{O}\right)_{3}\left[\mathrm{Co}(\mathrm{hmta}) \mathrm{SbW}_{8} \mathrm{O}_{31}\right]_{3}\right\}\right]^{13-}$ formed in the presence of high concentrations of $\mathrm{Co}^{2+}$ (Fig. 4). As shown in Fig. 5, the CD spectra of the chiral crystals exhibited strong Cotton effects at $314,285,248$, and $211 \mathrm{~nm}$, indicating that polyoxoanion 2 possesses optical activity in aqueous solution. This also confirmed the chiral characteristic of the anion cluster. The CD spectra of the two products were mirror images, and they possessed similar powder X-ray diffraction (PXRD) patterns

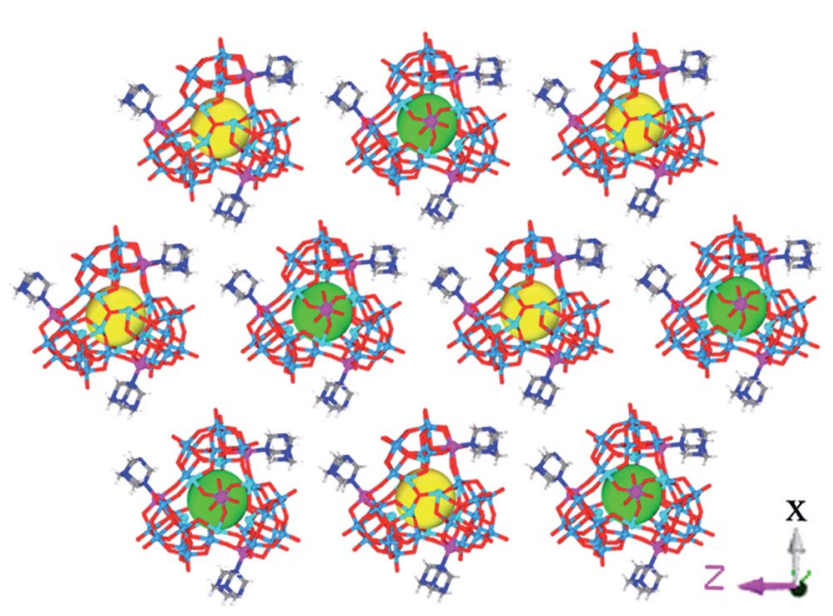

Fig. 3 The $\Delta$ - and $\Lambda$-enantiomers arranged in the racemic crystal. Hhmta and water molecules are omitted for clarity.

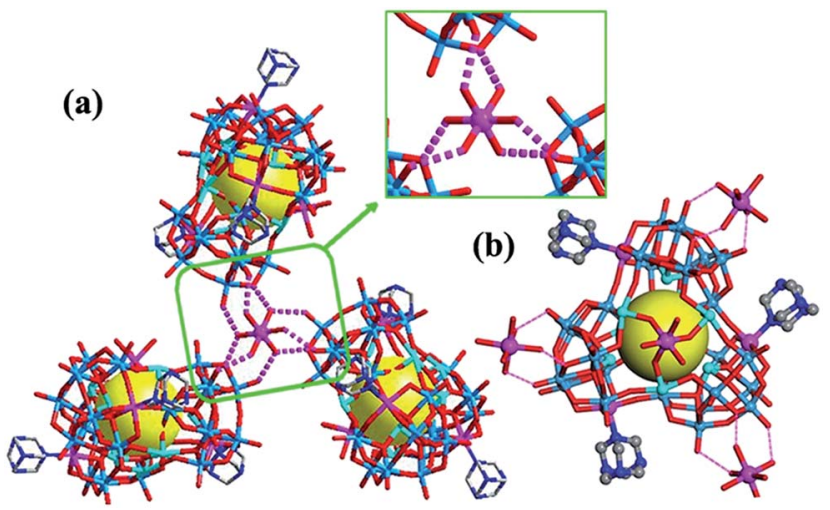

Fig. 4 (a) The chiral $\mathrm{Co}^{2+}$ centre formed by coordinating three homochiral polyoxoanions via $\mathrm{H}$-bonding interactions in $\Delta$-2; (b) each microanion was connected to three $\left[\mathrm{Co}\left(\mathrm{H}_{2} \mathrm{O}\right)_{6}\right]^{2+}$ groups in this $3 \mathrm{D}$ structure, imparting chirality to the whole crystal. Counter Hhmta and water molecules are omitted for clarity.

(Fig. 5a), which conclusively demonstrates that they are enantiomers.

Afterward, a single crystal was selected and dissolved in deionized water with sonication. A powder sample batch randomly picked from the bulk products was also dissolved in deionized water. Held at the same concentration, the two solutions were tested by $\mathrm{CD}$ and UV-vis measurements, respectively (Fig. 5b and S7†). As shown in Fig. 5b, the CD spectrum of the powder sample was almost identical to that of the single crystal at the same concentration, which revealed that the bulk samples of 2 crystallized in enantiopure form. Moreover, the CD spectra of mixtures of all the starting materials in
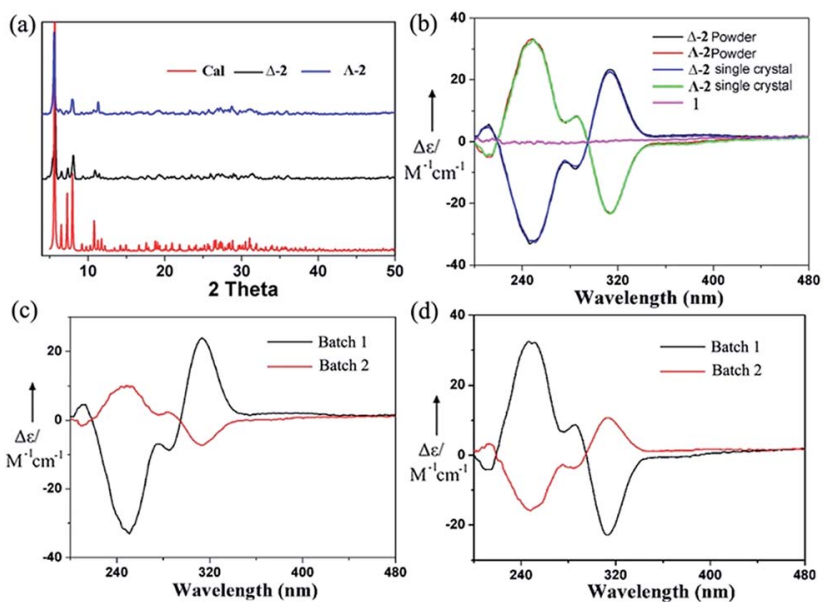

Fig. 5 (a) Calculated and experimental PXRD patterns of $\Delta-2$ and $\Lambda-2$; the peak positions of a simulated and experimental PXRD pattern at $20^{\circ} \mathrm{C}$ are in agreement with each other; (b) CD spectra for one chiral single crystal, powder samples, and one achiral single crystal in deionized water at the same concentration (1.49 $\mathrm{mg} \mathrm{mL}^{-1}$ ); (c) and (d) CD spectra of chiral powder samples obtained by the first crystallization and second crystallization processes; (c) shows that the $\Delta$-type POM was isolated in the first batch and the $\Lambda$-enantiomer was isolated in the second batch, and (d) shows that the $\Lambda$-type POM was isolated in the first batch and the $\Delta$ enantiomer was isolated in the second batch. 
the water solution and the filtrate after the reaction did not exhibit any peaks (Fig. 5b and S8d $\dagger$ ). After collecting the first batch of large tetrahedral crystals from the solution and allowing the water in the filtrate to slowly evaporate, another batch of small triangular crystals could be obtained. CD spectra indicated that the individual crystals obtained from the second batch exhibited the opposite chirality. However, the decrease of Cotton effects in the CD spectra of the bulk powder samples showed their reduced optical purity (Fig. 5c and d). These results indicated that the two enantiomers both formed in the reaction but crystallized out of the solution at different crystallization rates. We can conclude that chiral symmetry breaking and chiral autocatalysis occurred during the crystallization process. $^{21}$

The nucleation of a monochiral crystal is a symmetrybreaking event on the microscale, and the nonlinear autocatalytic dynamics of secondary nucleation leads to chiral amplification and the eventual production of enantiopure crystals. In this process, the entire chirality should be influenced by the chirality of the primary nucleus. The probability of attaining a left- or right-handed chiral form should be random in a symmetry-breaking event in the absence of any chiral influence. To this end, we carried out 60 crystallization experiments and performed CD studies on each of the first batch crystals. We found that 33 of these crystallizations gave $\Delta$-enantiomers in their first batches, while 27 of these crystallizations afforded $\Lambda$ enantiomers. Slow crystallization favored the formation of a homochiral high-nuclearity polytungstate assembly from achiral precursors. CD spectroscopy and single X-ray analysis showed that the chiral molecular capsule still possessed a highlevel of self-recognition during the fast crystallization process with a high concentration of $\mathrm{Co}^{2+}$ ions, leading to homochiral individual crystals (Fig. S $8 \dagger$ ). However, the decrease of the CD peaks of the bulk samples compared to that of the single crystal at the same concentration indicated that some crystals with opposite handedness were formed from the solution in a fast crystallization process, resulting in a lower optical purity.

Achiral single crystal samples with a rhomboid shape (1) composed of the same polyoxoanions could be isolated by decreasing the concentration of $\mathrm{Co}^{2+}$ in the reaction (to $\leq 46$ $\mathrm{mM}$ ). No Cotton effects were observed on the CD spectra of individual single crystals (Fig. 5b). The defined structures of the racemic and homochiral crystals thus provided a chance to study delicate interactions at the molecular-level for chiral recognition and propagation. As shown in Fig. 4, the co-crystallization of anion clusters and $\left[\mathrm{Co}\left(\mathrm{H}_{2} \mathrm{O}\right)_{6}\right]^{2+}$ groups resulted in homochiral crystals. Each $\left[\mathrm{Co}\left(\mathrm{H}_{2} \mathrm{O}\right)_{6}\right]^{2+}$ group was coordinated with three homochiral microanions through H-bonding interactions, with the typical H-bond length in the range of 2.6-2.9 A. The three homochiral microanions could be regarded as three bidentate ligands coordinated with the central $\left[\mathrm{Co}\left(\mathrm{H}_{2} \mathrm{O}\right)_{6}\right]^{2+}$ group to form the shape of a $\Delta$ or $\Lambda$ propeller. The chiral microanion self-sorted via the chiral $\left[\mathrm{Co}\left(\mathrm{H}_{2} \mathrm{O}\right)_{6}\right]^{2+}$ groups into homochiral materials (Fig. 4). This illustrated that H-bonding interactions are responsible for such high-level chiral recognition, in a process similar to the supramolecular chirality frequently observed in biology. ${ }^{22}$ In comparison, without the co- crystallization of $\mathrm{Co}^{2+}$ ions, two enantiomers were arranged alternately, resulting in racemic crystals of compound 1 (Fig. 3).

\section{Stability}

The stability of the POMs in aqueous solutions of different $\mathrm{pH}$ values was investigated by UV-vis spectroscopy and cyclic voltammetry (CV). Compound 2 was dissolved in aqueous solutions of $\mathrm{pH}$ 5-9 and kept at room temperature. The UV-vis spectra of these solutions were taken every hour. No changes were observed in the UV-vis spectra at $\mathrm{pH}$ 5-8 after a 6-hour incubation, suggesting that 2 is stable in pH 5-8 buffer solutions (Fig. $\mathrm{S} 12 \mathrm{a}-\mathrm{d} \dagger$ ). In the $\mathrm{pH}=9$ buffer solution, the absorbance of 2 decreased over time (Fig. S12 $\dagger$ ), indicating that 2 is unstable at that $\mathrm{pH}$. To further confirm the stability of the POMs, the CV behaviors of 2 in $\mathrm{pH}$ 5-8 buffer solutions were obtained. No obvious changes in the $\mathrm{CV}$ characteristics were observed during 6-hour treatments (Fig. S12f-i†). We further studied the solution structure by ESI-MS. After compound 1 was dissolved in a pH 7 buffer solution and aged for 24 hours, ESIMS spectra confirmed the existence of 1 (Fig. S13 and Table $\mathrm{S} 2 \dagger)$, which was in agreement with the solid state structures from X-ray diffraction experiments. These results confirm that the POMs are structurally stable in pH 5-8 aqueous solutions.

\section{Cytotoxicity}

In order to determine whether the present POMs possess antitumor activities and on which cell lines they are more effective, we studied their cytotoxicity against eight cancer cell lines, including four ovarian cancer cell lines, two colon cancer cell lines, one non-small lung cancer cell line and one breast cancer cell line, by the (3-(4,5-dimethylthiazol-2-yl)-5-(3-carboxymethoxyphenyl)-2-(4-sulfophenyl)-2H-tetrazolium) (MTS) assay (Fig. S14, Tables 1, S3 and S4†). The cytotoxicity of rac-1 was similar to both $\Delta-2$ and $\Lambda-2$, and significantly higher than that of $\left\{\mathrm{Sb}_{9} \mathrm{~W}_{21}\right\}$ on all tested cell lines. Specifically, 1 and 2 showed a higher cytotoxicity on A2780, A2780cisR, and OVCAR-3 cells than on other cells, which meant that they are very effective on ovarian cancer cell lines. The $\mathrm{IC}_{50}$ values (the concentration for a $50 \%$ growth inhibition) of 1 on these three cell lines were 0.77 $\pm 0.01,4.35 \pm 0.20$, and $1.78 \pm 0.07 \mu \mathrm{M}$, respectively. In addition, hmta and $\mathrm{NH}_{4} \mathrm{Cl}$ showed no cytotoxicity on all tested cell lines, even at very high concentrations (>500 and $900 \mu \mathrm{M}$, respectively). Although $\mathrm{CoCl}_{2}$ exhibited some cytotoxicity on $\mathrm{A} 2780$ and $\mathrm{A} 2780$ cisR cells, its $\mathrm{IC}_{50}$ values $(122.7 \pm 3.21$ and $114.6 \pm 9.75 \mu \mathrm{M}$, respectively) were significantly higher than

Table $1 \quad \mathrm{IC}_{50}$ values $(\mu \mathrm{M})$ of POMs against A2780, A2780cisR, and OVCAR-3 cells after a 72-hour incubation, as determined by the MTS assay. Data are expressed as means \pm S.D. $(n=3)$

\begin{tabular}{lccc}
\hline & A2780 cells & A2780cisR cells & OVCAR-3 cells \\
\hline $\mathbf{1}$ & $0.77 \pm 0.01$ & $4.35 \pm 0.20$ & $1.78 \pm 0.07$ \\
$\Delta-2$ & $0.78 \pm 0.01$ & $4.51 \pm 0.25$ & $1.81 \pm 0.01$ \\
$\Lambda-2$ & $0.80 \pm 0.03$ & $4.42 \pm 0.11$ & $1.80 \pm 0.08$ \\
$\left\{\mathrm{Sb}_{9} \mathrm{~W}_{21}\right\}$ & $4.44 \pm 0.13$ & $29.02 \pm 1.31$ & $8.80 \pm 0.18$
\end{tabular}


those of 1 and $\left\{\mathrm{Sb}_{9} \mathrm{~W}_{21}\right\}$. These results indicated that the higher cytotoxicity of 1 and 2 over $\left\{\mathrm{Sb}_{9} \mathrm{~W}_{21}\right\}$ was derived from POM assemblies, not the addition of other components. We also determined the cytotoxicity of POMs against normal cell line HEK-293 cells. The $\mathrm{IC}_{50}$ value of POMs on HEK-293 cells is around $16 \mu \mathrm{M}$, which is $\sim 20-$, 8.9- and 3.6-fold higher than that on A2780, OVCAR-3 and A2780cisR cells, respectively (Fig. S16 and Table $56 \dagger$ ). These results demonstrated the potential use of POMs for the treatment of ovarian cancer.

\section{Cellular uptake}

Encouraged by the high cytotoxicity of POMs against A2780 and A2780cisR cells, the cellular uptake of POMs on both cell lines was investigated by directly measuring the metal content in the cells using inductively coupled plasma-mass spectrometry (ICPMS, Agilent technologies, Santa Clara, CA) (Fig. 6a and S17 $\dagger$ ). After incubation for 4 hours at an equivalent concentration of $20 \mu \mathrm{M}$, the $\mathrm{Sb}$ content in A2780 cells was $0.78 \pm 0.04,0.74 \pm$ $0.04,0.75 \pm 0.04$, and $2.44 \pm 0.08 \mathrm{nmol}$ per $10^{6}$ cells, and the $\mathrm{W}$ content was $2.02 \pm 0.10,2.08 \pm 0.11,2.03 \pm 0.10$, and $5.74 \pm$ $0.29 \mathrm{nmol}$ per $10^{6}$ cells for $1, \Delta-2, \Lambda-2$, and $\left\{\mathrm{Sb}_{9} \mathrm{~W}_{21}\right\}$, respectively. In addition, the Co content in A2780 cells was $0.36 \pm 0.02$, $0.40 \pm 0.03$, and $0.41 \pm 0.03 \mathrm{nmol}$ per $10^{6}$ cells for $1, \Delta-2$, and $\Lambda-2$, respectively. These results indicated that the uptake of 1 is similar to 2 , and three times less than that of $\left\{\mathrm{Sb}_{9} \mathrm{~W}_{21}\right\}$. The molar ratio of internalized $\mathrm{Sb}$ to $\mathrm{W}$ was $0.38 \pm 0.01,0.36 \pm 0.02$,

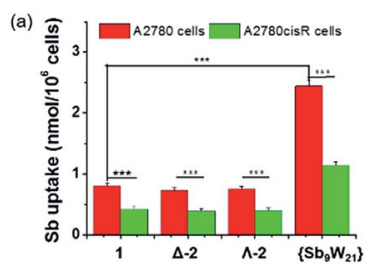

(c)
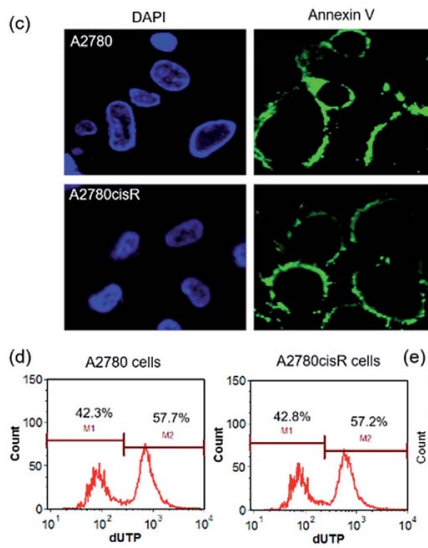

A2780cisR cells (e)
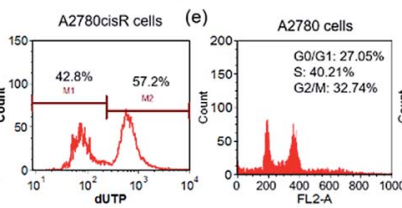

30 cells
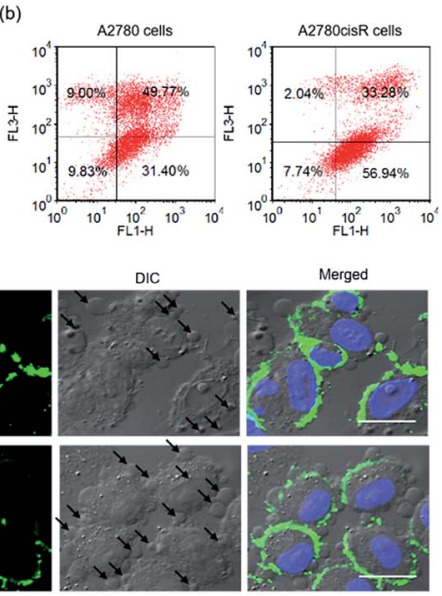

Fig. 6 (a) Uptake of Sb by A2780 and A2780cisR cells incubated with POMs for 4 hours (*** $P<0.001$ ); (b) quantitative analysis of apoptosis induced by 1 in A2780 and A2780cisR cells; (c) CLSM images showing cell apoptosis induced by 1 in A2780 and A2780cisR cells. The apoptotic bodies are labeled with black arrows. Scale bars: $20 \mu \mathrm{m}$; (d) flow cytometric analysis of the apoptotic and non-apoptotic populations of $A 2780$ and $A 2780$ cisR cells treated with 1 by a TUNEL assay; (e) cell cycle analysis of A2780 and A2780cisR cells incubated with 1 for 24 hours. and $0.37 \pm 0.01$ (around $9: 24$ ) for $1, \Delta-2$, and $\Lambda-2$, and $0.43 \pm$ 0.01 (approximately $9: 21$ ) for $\left\{\mathrm{Sb}_{9} \mathrm{~W}_{21}\right\}$, and the molar ratio of internalized Co to $\mathrm{Sb}$ was $0.46 \pm 0.03$ (around $4: 9$ ) for 1 and $0.54 \pm 0.01$ and $0.55 \pm 0.02$ (roughly $5: 9$ ) for $\Delta-2$ and $\Lambda-2$, respectively. These ratios did not significantly deviate from those expected for the POMs, suggesting that the POMs and $\left\{\mathrm{Sb}_{9} \mathrm{~W}_{21}\right\}$ remain intact upon cellular uptake. The same molar ratio on A2780cisR cells was also observed, except that the uptake of the title compounds and $\left\{\mathrm{Sb}_{9} \mathrm{~W}_{21}\right\}$ on A2780cisR cells was about two times less than on A2780 cells, which may explain the lower cytotoxicity of POMs on A2780cisR cells than on A2780 cells. The cellular uptake of POMs on A2780 cells in the presence or absence of $10 \%$ FBS was also determined (Fig. S18†). No difference in the cellular uptake was observed for the POMs incubated with or without FBS, indicating that FBS in the cell medium did not block the uptake of POMs.

\section{Apoptosis analysis}

It has been reported that POMs can exert cytotoxicity by inducing apoptosis of cancer cells. ${ }^{\mathbf{1 7 b}, \mathbf{1 8 a}}$ Thus, a flow cytometry assay was performed to see whether the present POMs can induce apoptosis on A2780 and A2780cisR cells. As shown in Fig. $6 \mathrm{~b}$ and $S 19, \uparrow 1, \Delta-2$, and $\Lambda-2$ induced very high levels of cell apoptosis, resulting in $81.17 \%, 80.96 \%$, and $80.36 \%$ apoptotic cells in A2780 cells, and 90.22\%, 88.68\%, and 85.16\% apoptotic cells in A2780cisR cells, respectively. However, $\left\{\mathrm{Sb}_{9} \mathrm{~W}_{21}\right\}$ at the same concentration barely induced cell apoptosis on either cell line. These results suggest that the antitumor activity of POMs is attributable at least in part to the activation of the apoptotic pathway in cancer cells.

The cell apoptosis induced by POMs was also confirmed by confocal laser scanning microscopy (CLSM) (Fig. 6c and S20†). Most of the cells treated with POMs appeared to have apoptotic morphologies, as shown by membrane blebbing and the appearance of the membrane-associated apoptotic bodies. In addition, the presence of bright green fluorescence from Annexin V in the cells treated with POMs confirmed that POMs could successfully induce cancer cell apoptosis. On the contrary, an apoptotic morphology and green fluorescence were not observed in cells treated with $\left\{\mathrm{Sb}_{9} \mathrm{~W}_{21}\right\}$, indicating that $\left\{\mathrm{Sb}_{9} \mathrm{~W}_{21}\right\}$ could not induce cell apoptosis at the same concentration. These results were consistent with the quantitative results of flow cytometry.

DNA fragmentation provided additional support for apoptosis. During apoptosis, activated nucleases degrade the higher order chromatin structure of DNA into fragments, which can be extracted from cells and visualized by gel electrophoresis followed by ethidium bromide staining. As shown in Fig. S21, $\dagger$ the presence of the characteristic DNA ladder in lanes 3-5 suggested that POMs can induce significant apoptosis in both cell lines. In contrast, the absence of the DNA ladder in lane 6 indicated that $\left\{\mathrm{Sb}_{9} \mathrm{~W}_{21}\right\}$ could not induce apoptosis in these cell lines. The DNA fragments were further quantified by a terminal deoxynucleotidyl transferase mediated dUTP nick end labeling (TUNEL) assay (Fig. $6 \mathrm{~d}$ and S22 $\dagger$ ). POMs resulted in $\sim 55 \%$ of apoptotic cells in both $\mathrm{A} 2780$ and A2780cisR cells. In contrast, 
cells treated with $\left\{\mathrm{Sb}_{9} \mathrm{~W}_{21}\right\}$ at the same concentration did not show any apoptotic characteristics.

\section{Cell cycle analysis}

The ability to proliferate indefinitely is one of the identifying characteristics of cancer cells, and is key to tumor growth and development. The alteration of the cell cycle induced by POMs was analyzed by determining the amount of DNA in the cells. As shown in Fig. 6e and S23, $\dagger$ most of the blank cells are in the $\mathrm{G}_{0} /$ $\mathrm{G}_{1}$ phase, suggesting that the cells were preparing for DNA synthesis. The cell cycle significantly changed after treatment with $1, \Delta-2$, and $\Lambda-2$, with the ratio of the $G_{0} / G_{1}$ phase decreasing by $52.2 \%, 46.2 \%$, and $45.3 \%$ in A2780 cells, and $33.9 \%, 37.1 \%$, and $39.3 \%$ in A2780cisR cells, respectively. Likewise, the percentage of the $\mathrm{G}_{2} / \mathrm{M}$ phase increased 2.57-, 2.01-, and 2.26-fold in A2780 cells, and 1.85-, 1.27-, and 1.96-fold in A2780cisR cell, respectively, after treatment with 1, $\Delta-\mathbf{2}$, and $\Lambda$-2. These results indicated that POMs can inhibit cancer cell proliferation by blocking the cell cycle. However, cells treated with $\left\{\mathrm{Sb}_{9} \mathrm{~W}_{21}\right\}$ exhibited a cell cycle similar to the control cells, suggesting that $\left\{\mathrm{Sb}_{9} \mathrm{~W}_{21}\right\}$ could not change the cell cycle at a comparable concentration.

\section{Protein binding studies}

When drugs are bound to proteins, the resulting protection from metabolic degradation can prolong their activity. The proportion of drug molecules bound to the protein depends on the total drug concentration and the drugs' affinity to the protein. The distribution and metabolism of many biologically active compounds are correlated with their affinities to serum albumin, the most abundant protein in blood plasma, accounting for about $60 \%$ of its total protein. Thus, an investigation of the interaction between these compounds and serum albumin can provide important information on their potential as therapeutic drugs. ${ }^{23}$

The interaction of POMs with bovine serum albumin (BSA) was investigated using multi-spectroscopic methods. UV-vis absorption measurements indicate the structure and the conformation of the complex. As shown in Fig. S24 and Table $\mathrm{S} 7, \dagger \mathrm{BSA}$ displayed a strong absorption peak at $204 \mathrm{~nm}$, which represents the content of an $\alpha$-helix structure. After the addition of POMs, the peak intensity decreased, which was accompanied by a bathochromic shift from $204 \mathrm{~nm}$ to $210 \mathrm{~nm}$. The absorbance at $280 \mathrm{~nm}$, mainly coming from tryptophan, tyrosine, and phenylalanine, increased in the presence of increasing amounts of POMs. The changes in the characteristic absorption indicated that POMs can interact with BSA, and this interaction may change the structure of BSA by decreasing the number of $\alpha$-helix structures. Interestingly, the increase in the absorbance at 280 $\mathrm{nm}$ of BSA titrated with $\left\{\mathrm{Sb}_{9} \mathrm{~W}_{21}\right\}$ (about 18\%) was much lower than when it was titrated with POMs (approximately 35\%), which indicated that $\left\{\mathrm{Sb}_{9} \mathrm{~W}_{21}\right\}$ may form fewer complexes with BSA than POMs do.

An intrinsic fluorescence study was performed to evaluate the changes in structure that were caused by the reaction of BSA with POMs. Fig. S25† shows a conspicuous change in the fluorescence emission spectra of BSA with the addition of various amounts of POMs. In the absence of POMs, the relative fluorescence intensity of BSA was about 70; in the presence of POMs, the relative fluorescence intensities obviously decreased to $35,31,34$, and 48 for $\mathbf{1}, \Delta-\mathbf{2}, \Lambda-2$, and $\left\{\mathrm{Sb}_{9} \mathrm{~W}_{21}\right\}$, respectively, which were equivalent to reductions of $51.4 \%, 54.5 \%, 53.4 \%$, and $32.4 \%$, respectively (Fig. 7a). These phenomena and analyses suggested that POMs could bind to BSA, and that the binding induces some changes in the microenvironment of the tryptophan residues. ${ }^{24}$ The lower quenching effect of $\left\{\mathrm{Sb}_{9} \mathrm{~W}_{21}\right\}$ was consistent with the UV results, and suggested that $\left\{\mathrm{Sb}_{9} \mathrm{~W}_{21}\right\}$ forms fewer complexes with BSA than POMs do.

The fluorescence quenching data were further analyzed by the Stern-Völmer equation: ${ }^{25}$

$$
F_{0} / F=1+K_{\mathrm{sv}}[\mathrm{Q}]=1+K_{\mathrm{q}} \tau_{0}[\mathrm{Q}]
$$

where $F_{0}$ and $F$ are the fluorescence intensities without and with quenchers. $K_{\mathrm{q}}$ is the quenching rate constant of the biomolecule, $K_{\mathrm{sv}}$ is the Stern-Volmer dynamic quenching constant, $\tau_{0}$ is the average lifetime of the molecule without the quencher $\left(10^{-8}\right.$ s) and $[\mathrm{Q}]$ is the concentration of the quencher, respectively.
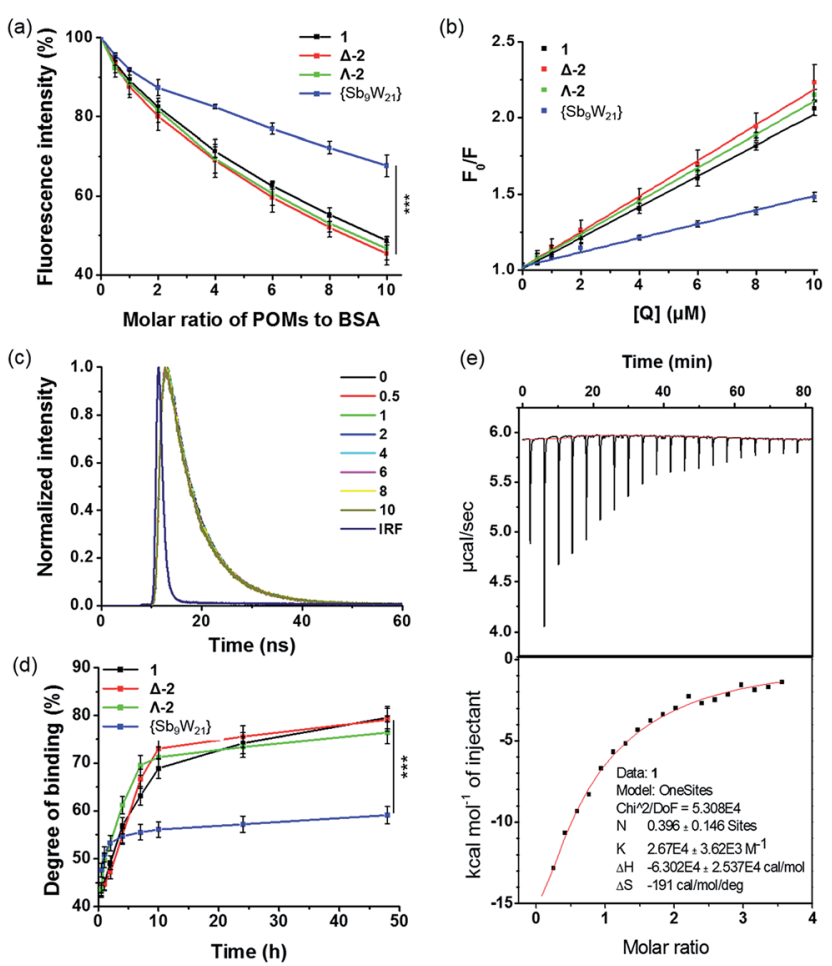

Fig. 7 (a) Decrease in the fluorescence of BSA in the presence of increasing amounts of POMs (*** $P<0.001)$; (b) Stern-Völmer curves of the POMs-BSA systems; (c) time-resolved fluorescence decay traces of BSA titrated with 1, with a molar ratio of 1 to BSA of $0-10$. "IRF" in the figure stands for Instrument Response Function; (d) binding of POMs to BSA at variable reaction times (***P<0.001); (e) calorimetric data for the titration of BSA with 1 . The binding isotherm (heat change vs. POM/BSA molar ratio) was obtained from the integration of raw data and was fitted to a "one-site" model. 
As shown in Fig. $7 \mathrm{~b}$ and Table $\mathrm{S} 8, \dagger$ the values of $K_{\mathrm{q}}$ for $\mathbf{1}, \Delta-\mathbf{2}$, $\Lambda-2$, and $\left\{\mathrm{Sb}_{9} \mathrm{~W}_{21}\right\}$ were $(1.02 \pm 0.03) \times 10^{13},(1.18 \pm 0.21) \times$ $10^{13},(1.11 \pm 0.89) \times 10^{13}$, and $(0.45 \pm 0.06) \times 10^{13} \mathrm{~L}(\mathrm{~mol} \mathrm{~s})^{-1}$, respectively, which were greater than the value of the maximum scatter collision quenching constant $\left(2.0 \times 10^{10} \mathrm{~L}(\mathrm{~mol} \mathrm{~s})^{-1}\right)$. Therefore, the quenching was more of a static quenching that was initiated by complex formation, rather than by dynamic collision.

Dynamic and static quenching mechanisms can also be distinguished by changes in the fluorescence lifetime. The lifetime decreases with the addition of quenchers for dynamic quenching, while no change is observed for static quenching. The static quenching mechanism was further confirmed by the lifetime determination, with no decrease observed for the lifetime of BSA after the addition of POMs and $\left\{\mathrm{Sb}_{9} \mathrm{~W}_{21}\right\}$ (Fig. $7 \mathrm{c}$ and $\mathrm{S} 26 \dagger$ ).

The in vitro binding of POMs to serum albumin was quantified by an ICP-MS assay (Fig. 7d). The binding of POMs to albumin occurred practically immediately, with about $45 \%$ of POMs bound to BSA after a 30-minute incubation. The binding degree then increased to about $70 \%$ after a 10 -hour incubation and reached about $80 \%$ after 48 hours of incubation. $\left\{\mathrm{Sb}_{9} \mathrm{~W}_{21}\right\}$ also showed fast binding to BSA, but only $60 \%$ of $\left\{\mathrm{Sb}_{9} \mathrm{~W}_{21}\right\}$ was bound to BSA after 48 hours of incubation, confirming the higher affinity of POMs to BSA than $\left\{\mathrm{Sb}_{9} \mathrm{~W}_{21}\right\}$.

The binding constants of POMs to BSA were determined by isothermal titration calorimetry (ITC). The binding constants for $1, \Delta-2, \Lambda-2$, and $\left\{\mathrm{Sb}_{9} \mathrm{~W}_{21}\right\}$ were determined to be $(2.67 \pm 0.36)$ $\times 10^{4},(2.31 \pm 0.22) \times 10^{4},(2.36 \pm 0.30) \times 10^{4}$, and $(1.68 \pm 0.44)$ $\times 10^{4} \mathrm{M}^{-1}$, respectively. In addition, about $40 \%$ of POMs were bound to BSA, while only $13 \%$ of $\left\{\mathrm{Sb}_{9} \mathrm{~W}_{21}\right\}$ interacted with BSA (Fig. 7e and $\mathrm{S} 27 \dagger$ ). The protein binding studies demonstrated that POMs can bind to proteins, likely through electrostatic interactions, with a higher affinity than $\left\{\mathrm{Sb}_{9} \mathrm{~W}_{21}\right\}$, which may explain their greater cytotoxicity. We believe that, after internalization, POMs affect the cellular function by binding to the proteins in the cells, thereby inducing cell apoptosis and resulting in cell death. $\left\{\mathrm{Sb}_{9} \mathrm{~W}_{21}\right\}$ had a lower affinity to proteins than POMs, which resulted in less cell apoptosis and a lower cytotoxicity, although it showed a higher cellular uptake than POMs.

\section{Conclusions}

In summary, homochiral crystalline materials were synthesized from achiral precursors via chiral symmetry breaking and asymmetric autocatalysis. During crystallization, the enantiomers showed a high level of chiral recognition, causing them to crystallize into individual enantiopure crystals through a counterion-mediated interaction. Detailed structural analysis revealed that $\mathrm{H}$-bonding interactions are responsible for such high-level chiral recognition, in a process similar to the supramolecular chirality frequently observed in biology. The successful synthesis of the POM-based materials in their homochiral forms not only provided rare examples of homochiral materials, but also suggested a new structural model for studying the chemical origins of life. In addition, the POMs synthesized here were effective against various cancer cells, especially resistant ovarian cancer cells. The POMs could block the cell cycle and complex with proteins with high affinities, thereby efficiently inducing cell apoptosis and inhibiting cell proliferation. These results suggest that they are promising antitumor agents, especially for the treatment of resistant cancers and other hard-to-treat solid tumours.

\section{Experimental}

\section{Materials and instruments}

All the reagents were commercially purchased and used without further purification. The $\left(\mathrm{NH}_{4}\right)_{18}\left[\mathrm{NaSb}_{9} \mathrm{~W}_{21} \mathrm{O}_{86}\right] \cdot 24 \mathrm{H}_{2} \mathrm{O}$ precursor was synthesized according to the literature ${ }^{20}$ and characterized by IR spectroscopy. Elemental analyses of $\mathrm{Sb}, \mathrm{W}$, and Co were performed on a PLASMASPEC (I) ICP atomic emission spectrometer and Agilent 7700x ICP-MS and analyzed using an ICP-MS Mass Hunter version B01.03. IR spectra were recorded in the range $400-4000 \mathrm{~cm}^{-1}$ on an Alpha Centauri FTIR spectrophotometer using KBr pellets. UV-vis spectroscopy was performed with a Varian Cary 50 spectrophotometer in the range of 200-800 $\mathrm{nm}$. The PXRD data were recorded on a Bruker D8 Advance diffractometer. CD spectra were measured with a Jasco model J-810 spectropolarimeter. Time-domain lifetimes were measured on a ChronosBH lifetime fluorimeter (ISS, Inc.) using Time-Correlated Single Photon Counting (TCSPC) methods. The fluorimeter contained Becker-Hickl SPC-130 detection electronics and a HPM-100-40 Hybrid PMT detector. Excitation was provided by a $280 \mathrm{~nm}$ nanosecond pulsed LED. Emission wavelengths were selected with interference filters (Semrock BrightlineFF01-341/LP). The Instrument Response Function (IRF) was measured to be approximately 120 ps FWHM in a $1 \%$ scattering solution of Ludox LS colloidal silica. Lifetimes were fitted using a forward convolution method in the Vinci control and analysis software.

\section{Synthesis}

Synthesis of 1. $\left(\mathrm{NH}_{4}\right)_{18}\left[\mathrm{NaSb}_{9} \mathrm{~W}_{21} \mathrm{O}_{86}\right] \cdot 24 \mathrm{H}_{2} \mathrm{O}(0.60 \mathrm{~g}, 0.085$ $\mathrm{mmol})$ was dissolved in distilled water $(10 \mathrm{~mL})$, to which solid $\mathrm{CoCl}_{2} \cdot 6 \mathrm{H}_{2} \mathrm{O}(0.10 \mathrm{~g}, 0.42 \mathrm{mmol})$ was added with strong stirring. The $\mathrm{pH}$ value of the mixture was adjusted to 7.40 with a $1.2 \mathrm{M}$ hmta solution, and then solid $\mathrm{NaOH}$ was added to adjust the $\mathrm{pH}$ value to 8.50. The resulting mixture was heated at $100{ }^{\circ} \mathrm{C}$ for 2 hours. After the reaction, the $\mathrm{pH}$ value was 7.50. The filtrate was kept at room temperature with slow evaporation for 6 days, resulting in big purple rhomboid shaped crystals of $\mathbf{1}$ (yield $c a$. $110 \mathrm{mg}$ ). Anal. found (\%): Co, 2.61; Sb, 12.01; W, 47.82; calcd: Co, 2.47; Sb, 11.47; W, 46.20.

Synthesis of 2. $\left(\mathrm{NH}_{4}\right)_{18}\left[\mathrm{NaSb}_{9} \mathrm{~W}_{21} \mathrm{O}_{86}\right] \cdot 24 \mathrm{H}_{2} \mathrm{O}(0.6 \mathrm{~g}, 0.085$ $\mathrm{mmol})$ was dissolved in distilled water $(10 \mathrm{~mL})$, to which solid $\mathrm{CoCl}_{2} \cdot 6 \mathrm{H}_{2} \mathrm{O}(0.15 \mathrm{~g}, 0.63 \mathrm{mmol})$ was added with strong stirring. The $\mathrm{pH}$ value of the mixture was carefully adjusted to 7.20 with a 1.2 $\mathrm{M}$ hmta solution, and then solid $\mathrm{NaOH}$ was added in this system to adjust the $\mathrm{pH}$ value to 8.0. The resulting mixture was heated at $100{ }^{\circ} \mathrm{C}$ for 2 hours. After the reaction, the $\mathrm{pH}$ value was 7.30. The filtrate was kept at room temperature with slow 
evaporation for 28 days, resulting in big purple tetrahedral crystals of 2 (yield $c a .20 \mathrm{mg}$ ). After collecting these crystals, the filtrate was kept at room temperature for 3 days, resulting in another batch of small purple triangular shaped crystals (yield ca. $88 \mathrm{mg}$ ). Anal. found (\%): Co, 3.07; Sb, 11.89; W, 48.08; calcd: Co, 3.17; Sb, 11.77; W, 47.39. IR (KBr pellet): $\nu_{\max } / \mathrm{cm}^{-1} 3403$ (m), $1634(\mathrm{~m}), 1462(\mathrm{~s}), 1434(\mathrm{w}), 1382(\mathrm{w}), 1312(\mathrm{w}), 1261(\mathrm{~m})$, $1246(\mathrm{~s}), 1231(\mathrm{~m}), 1149(\mathrm{w}), 1060(\mathrm{w}), 1024(\mathrm{~s}), 1002(\mathrm{~m}), 940(\mathrm{~s})$, $804(\mathrm{~s}), 705(\mathrm{~s}), 526(\mathrm{w})$ and $460(\mathrm{w})$.

\section{X-ray crystallography}

The single crystal X-ray diffraction of $\mathbf{1}$ was collected with a Bruker APEX II CCD based detector at ChemMatCARS (Sector 15), Advanced Photon Source (APS), Argonne National Laboratory. The frames were integrated with the Bruker SAINT build in the APEX II software package using a narrow-frame integration algorithm, which also corrects for the Lorentz and polarization effects. The crystallographic data was performed on an Oxford Diffraction Gemini R CCD for 2. The data were collected at 293 $\mathrm{K}$, and with graphite-monochromated Mo-K $\alpha$ radiation $(\lambda=$ $0.71073 \AA$ ). These structures were solved by the direct method and refined by full-matrix least squares on $F^{2}$ using the SHELXL97 software. ${ }^{26}$ During the refinement of compounds $\mathbf{1}$ and 2 , the command 'isor' was used to restrain the non-H atoms with ADP and NPD problems, which led to restraint values of 322 and 143 for 1 and 2, respectively. The command 'omit-3 50' was used to omit the weak reflection above 50 degrees for 2 . There were a number of short connections between $\mathrm{OW}($ water $) \cdots \mathrm{O}(\mathrm{POM})$ in the range of 2.50-2.90 $\AA$, suggesting extensive H-bonding interactions between the lattice water molecules and POMs. All hydrogen atoms on water molecules, protonation, and the counter $\mathrm{NH}_{4}{ }^{+}$were directly included in the molecular formula. Carbon and the nitrogen-bound hydrogen atoms of the hmta molecules were placed in geometrically calculated positions. In the refinement, 14 and 18 lattice water molecules were found from the Fourier maps for compounds $\mathbf{1}$ and 2, respectively. However, there were still accessible solvent voids in the crystal structure, indicating that more water molecules should exist in the structure. On the basis of TG results, there should be another 15 water molecules in the formula unit, which were directly included in the molecular formula. The crystal data and structural refinements of compounds $\mathbf{1}$ and $\mathbf{2}$ are summarized in Table S1. $\dagger$ CCDC reference number 1431324 for $\mathbf{1}$ and 827684 for $\Delta-2$ contains the supplementary crystallographic data for this paper.

\section{Cell culture}

Cisplatin-sensitive human ovarian cancer cells A2780 and cisplatin resistant human ovarian cancer cells A2780cisR were obtained from Developmental Therapeutics Core, Northwestern University. Other cancer cells, including human ovarian cancer cells OVCAR-3 and SKOV-3, human colon cancer cells HT29 and CT26, human non-small lung cancer cells A549, human breast cancer cells MCF-7, and human embryonic kidney 293 (HEK293) cells were all obtained from the American Type Culture Collection (ATCC, Rockville, MD). A2780, A2780cisR, OVCAR-3,
CT26, and A549 cells were cultured in RPMI 1640 containing $10 \%$ fetal bovine serum (FBS, Gibco, Grand Island, NY). SKOV-3 and HT29 cells were grown in McCoy's 5A containing 10\% FBS. MCF-7 and HEK-293 cells were cultured in Dulbecco's Modified Eagle's Medium (DMEM) supplemented with 10\% FBS. All cells were cultured in a humidified atmosphere containing $5 \% \mathrm{CO}_{2}$ at $37^{\circ} \mathrm{C}$.

\section{Cytotoxicity assay}

Cells seeded in 96-well plates $\left(2 \times 10^{3}\right.$ cells per well $)$ were treated with different concentrations of POMs for 72 hours, and the cell viability was then measured by MTS (Promega, Madison, WI) according to the manufacturer's instructions. At the same time, the cytotoxicity of other components was also determined and they were used as controls. $\mathrm{IC}_{50}$ values were calculated from curves constructed by plotting cell survival (\%) versus drug concentration $(\mu \mathrm{M})$.

\section{Cellular uptake}

A2780 and A2780cisR cells seeded in 6-well plates $\left(5 \times 10^{4}\right.$ cells per well) were incubated with POMs $(20 \mu \mathrm{M})$ for 4 hours. Cells were then collected, washed with PBS, dried, and digested for metal analysis by ICP-MS. The uptake level was expressed as the amount of metal uptake associated per million cells.

\section{Apoptosis analysis}

For the flow cytometry assay, A2780 and A2780cisR cells were treated with POMs $(0.8 \mu \mathrm{M}$ and $4.5 \mu \mathrm{M}$, respectively) for 24 hours. Cells were then harvested, washed with PBS, stained with Alexa Fluor 488 conjugated Annexin V and PI for 15 minutes at room temperature in the dark, and analyzed by flow cytometry.

For Annexin V staining, A2780 and A2780cisR were seeded on $10 \mathrm{~mm}^{2}$ glass coverslips placed in 6-well plates. After treatment with POMs for 24 hours, cells were washed with PBS, fixed with $4 \%$ paraformaldehyde, and stained with DAPI and Alexa Fluor 488 conjugated Annexin V. The cells were then observed using CLSM.

For the DNA ladder, the total DNA was extracted from A2780 and A2780cisR cells incubated with POMs using a DNA ladder isolation kit (life technologies, Grand Island, NY) and examined for DNA fragmentation with $2 \%(\mathrm{w} / \mathrm{v})$ agarose gel electrophoresis at $35 \mathrm{~V}$ for 3 hours.

For the TUNEL assay, treated A2780 and A2780cisR cells were collected, washed with PBS, fixed with $70 \%$ ethanol at $4{ }^{\circ} \mathrm{C}$ overnight. Cells were then stained with an APO-BrdUTM TUNEL Assay Kit (Molecular Probes) according to the manufacturer's instructions, and analysed by flow cytometry.

\section{Cell cycle analysis}

A2780 and A2780cisR cells treated with POMs for 24 hours were collected, washed with PBS, fixed with $70 \%$ ethanol at $4{ }^{\circ} \mathrm{C}$ overnight and treated with RNase A for 45 min, followed by PI staining for 30 minutes. The alteration of the cell cycle was analysed by flow cytometry. 


\section{Protein binding studies}

BSA solution $(1 \mu \mathrm{M})$ in PBS $(\mathrm{pH}=7.2)$ was titrated with POMs from $0-10 \mu \mathrm{M}$. After equilibration, absorption spectra measurements were carried out on a Shimadzu UV-2401 spectrophotometer at 200-350 $\mathrm{nm}$. Fluorescence spectra were recorded using a Shimadzu RF-5301 spectrofluorophotometer from 300 to $400 \mathrm{~nm}$ at an excitation wavelength of $280 \mathrm{~nm}$. Time-domain lifetimes were measured on a ChronosBH lifetime fluorimeter (ISS, Inc.).

A mixture of POMs $(7.5 \mu \mathrm{M})$ and BSA solutions $\left(5 \mathrm{mg} \mathrm{mL}^{-1}\right)$ was incubated at $37{ }^{\circ} \mathrm{C}$. Aliquots were continuously taken and ultrafiltrated through a $30 \mathrm{kDa}$ cut-off filter (Millipore, Bedford, Ohio) for $15 \mathrm{~min}$ at $10000 \mathrm{rpm}$. The concentration of the free POMs in the ultrafiltrate was measured by ICP-MS. The degree of binding was calculated as:

$$
\left(C_{0}-C_{\text {free }}\right) / C_{0} \times 100 \%
$$

where $C_{0}$ and $C_{\text {free }}$ are the total concentration and the concentration of the free POMs, respectively.

Calorimetric titrations were carried out on a MicroCal iTC200 (MicroCal Inc., Northampton, MA), and the data were analyzed using the Origin software. Typically, $39 \mu \mathrm{L}$ of a POM solution $(500 \mu \mathrm{M})$ was injected into the BSA solution $(30 \mu \mathrm{M}$ in $200 \mu \mathrm{L}$ ) over $20-24 \mathrm{~s}$ at $240 \mathrm{~s}$ intervals using a $40 \mu \mathrm{L}$ syringe rotating at $1000 \mathrm{rpm}$. The initial delay (the hold period before injections) was set at $240 \mathrm{~s}$. Before use, samples were degassed at $25{ }^{\circ} \mathrm{C}$ using the ThermoVac accessory (provided by MicroCal Inc.).

\section{Acknowledgements}

This work was supported by the National Natural Science Foundation of China (21101022), the Science and Technology Development Project Foundation of Jilin Province (20150520001JH), and the National Science Foundation (DMR1308229). We thank Prof. T. Liu and Dr P. Yin at the University of Akron, and Dr C. He, Dr T. Zhang, and C. Poon at the University of Chicago for their experimental help and valuable suggestions. For the lifetime study, we acknowledge Dr J. Jureller and the Institute for Biophysical Dynamics NanoBiology Facility, funded by NIH (1S10RR026988). Single-crystal diffraction studies were performed at ChemMatCARS (Sector 15), APS, and Argonne National Laboratory. ChemMatCARS is principally supported by the Divisions of Chemistry (CHE) and Materials Research (DMR), and the National Science Foundation, under grant number NSF/CHE-1346572. Use of the APS, an Office of Science User Facility operated for the U.S. DOE Office of Science by Argonne National Laboratory, is supported by the U.S. DOE under Contract No. DE-AC02-06CH11357. We thank the University of Chicago Physical Science Division Mass Spectrometry for instrumentation.

\section{Notes and references}

1 (a) V. Soghomonian, Q. Chen, R. C. Haushalter, J. Zubieta and C. J. O'Connor, Science, 1993, 259, 1596; (b) J. Chin,
S. S. Lee, K. J. Lee, S. Park and D. H. Kim, Nature, 1999, 401, 254.

2 (a) L. Ma, C. Abney and W. Lin, Chem. Soc. Rev., 2009, 38, 1248; (b) L. Ma, J. M. Falkowski, C. Abney and W. Lin, Nat. Chem., 2010, 2, 838; (c) J. S. Seo, D. Whang, H. Lee, S. I. Jun, J. Oh, Y. J. Jeon and K. Kim, Nature, 2000, 404, 982. 3 (a) A. J. Tasiopoulos, A. Vinslava, W. Wernsdorfer, K. A. Abboud and G. Christou, Angew. Chem., Int. Ed., 2004, 43, 2117; (b) L. Zhang, R. Clérac, P. Heijboer and W. Schmitt, Angew. Chem., Int. Ed., 2012, 51, 3007; (c) C. D. Wu, A. Hu, L. Zhang and W. Lin, J. Am. Chem. Soc., 2005, 127, 8940; (d) Y. Liu, W. Xuan and Y. Cui, Adv. Mater., 2010, 22, 4112; (e) G. Novitchi, G. Pilet, L. Ungur, V. V. Moshchalkov, W. Wernsdorfer, L. F. Chibotaru, D. Luneau and A. K. Powell, Chem. Sci., 2012, 3, 1169.

4 (a) G. H. Wagnière, On Chirality and the Universal Asymmetry: Reflections on Image and Mirror Image, Wiley-VCH, 2007; (b) P. L. Luisi, The Emergence of Life: From Chemical Origins to Synthetic Biology, Cambridge Univ. Press, 2006.

5 (a) M. Szurgot, Cryst. Res. Technol., 2012, 47, 109; (b) C. Viedma and P. Cintas, Chem. Commun., 2011, 47, 12786; (c) S. B. Tsogoeva, S. Wei, M. Freund and M. Mauksch, Angew. Chem., Int. Ed., 2009, 48, 590; (d) K. Sato, Y. Itoh and T. Aida, Chem. Sci., 2014, 5, 136; (e) R. A. Rosenberg, D. Mishra and R. Naaman, Angew. Chem., Int. Ed., 2015, 127, 7403.

6 (a) A. Kuhnle, T. R. Linderoth, B. Hammer and F. Besenbacher, Nature, 2002, 415, 891; (b) C. Viedma, J. M. McBride, B. Kahr and P. Cintas, Angew. Chem., Int. Ed., 2013, 52, 10545; (c) X. Song, Y. Li, L. Gan, Z. Wang, J. $\mathrm{Yu}$ and R. Xu, Angew. Chem., Int. Ed., 2009, 48, 314; (d) Q. X. Yao, W. M. Xuan, H. Zhang, C. Y. Tu and J. Zhang, Chem. Commun., 2009, 59.

7 (a) K. Soai, T. Shibata, H. Morioka and K. Choji, Nature, 1995, 378, 767; (b) K. Sato, Y. Itoh and T. Aida, Chem. Sci., 2014, 5, 136; (c) S. T. Wu, Y. R. Wu, Q. Q. Kang, H. Zhang, L. S. Long, Z. Zheng, R. B. Huang and L. S. Zheng, Angew. Chem., Int. Ed., 2007, 46, 8475; (d) X. J. Kong, Y. Wu, L. S. Long, L. S. Zheng and Z. Zheng, J. Am. Chem. Soc., 2009, 131, 6918; (e) R. R. E. Steendam, J. M. M. Verkade, T. J. B. van Benthem, H. Meekes, W. J. P. van Enckevort, J. Raap, F. P. J. T. Rutjes and E. Vlieg, Nat. Commun., 2014, 5, 5543.

8 (a) A. Müller, F. Peters, M. T. Pope and D. Gatteschi, Chem. Rev., 1998, 98, 239; (b) H. Lv, Y. V. Geletii, C. Zhao, J. W. Vick-ers, G. Zhu, Z. Luo, J. Song, T. Lian, D. G. Musaev and C. L. Hill, Chem. Soc. Rev., 2012, 41, 7572; (c) D. L. Long, E. Burkholder and L. Cronin, Chem. Soc. Rev., 2007, 36, 105; (d) A. Dolbecq, E. Du-mas, C. R. Mayer and P. Mialane, Chem. Rev., 2010, 110, 6009; (e) A. Proust, R. Thouvenot and P. Gouzerh, Chem. Commun., 2008, 1837; (f) M. Nymanz and P. C. Burns, Chem. Soc. Rev., 2012, 41, 7354.

9 (a) F. Xin and M. T. Pope, J. Am. Chem. Soc., 1996, 118, 7731; (b) J. F. Garvey and M. T. Pope, Inorg. Chem., 1978, 17, 1115; (c) R. Acerete and J. Server-Carrió, J. Am. Chem. Soc., 1990, 112, 9386; (d) D. Y. Du, L. K. Yan, Z. M. Su, S. L. Li, Y. Q. Lan and E. B. Wang, Coord. Chem. Rev., 2013, 257, 702. 
10 (a) B. Hasenknopf, K. Micoine, E. Lacôte, S. Thorimbert, M. Malacria and R. Thouvenot, Eur. J. Inorg. Chem., 2008, 5001; (b) Y. Hou, X. Fang and C. L. Hill, Chem.-Eur. J., 2007, 13, 9442; (c) X. K. Fang, T. M. Anderson and C. L. Hill, Angew. Chem., Int. Ed., 2005, 44, 3540; (d) M. Inoue and T. Yamase, Bull. Chem. Soc. Jpn., 1995, 68, 3055.

11 (a) U. Kortz, M. G. Savelieff, F. Y. A. Ghali, L. M. Khalil, S. A. Maalouf and D. I. Sinno, Angew. Chem., Int. Ed., 2002, 41, 4070; (b) M. Carraro, A. Sartorel, G. Scorrano, C. Maccato, M. H. Dickman, U. Kortz and M. Bonchio, Angew. Chem., Int. Ed., 2008, 47, 7275; (c) M. Carraro, A. Sartorel, G. Scorrano, C. Maccato, M. H. Dickman, U. Kortz and M. Bonchio, Angew. Chem., Int. Ed., 2008, 47, 7275; (d) C. Streb, D. L. Long and L. Cronin, Chem. Commun., 2007, 471; (e) K. Micoine, B. Hasenknopf, S. Thorimbert, E. Lacôte and M. Malacria, Angew. Chem., Int. Ed., 2009, 48, 3466.

12 (a) Q. Han, C. He, M. Zhao, B. Qi, J. Niu and C. Duan, J. Am. Chem. Soc., 2013, 135, 10186; (b) S. Luo, J. Li, H. Xu, L. Zhang and J. Cheng, Org. Lett., 2007, 9, 3675; (c) C. Jahier, M. Cantuel, N. D. McClenaghan, T. Buffeteau, D. Cavagnat, F. Agbossou, M. Carraro, M. Bonchio and S. Nlate, Chem.Eur. J., 2009, 15, 8703; (d) Y. Wang, H. Li, C. Wu, Y. Yang, L. Shi and L. Wu, Angew. Chem., Int. Ed., 2013, 125, 4675; (e) Q. Han, B. Qi, W. Ren, C. He, J. Niu and C. Duan, Nat. Commun., 2015, 6, 10007; $(f)$ C. Braze, N. Dupré, M. Malacria, B. Hasenknopf, E. Lacôte and S. Thorimbert, Chem.-Eur. J., 2014, 20, 16074.

13 (a) H. Y. An, E. B. Wang, D. R. Xiao, Y. G. Li, Z. M. Su and L. Xu, Angew. Chem., Int. Ed., 2006, 45, 904; (b) Z. M. Zhang, Y. G. Li, S. Yao, E. B. Wang, Y. H. Wang and R. Clérac, Angew. Chem., Int. Ed., 2009, 48, 1581; (c) Z. M. Zhang, S. Yao, Y. G. Li, R. Clérac, Y. Lu, Z. M. Su and E. B. Wang, J. Am. Chem. Soc., 2009, 131, 14600.

14 (a) J. Zhang, J. Hao, Y. Wei, F. Xiao, P. Yin and L. Wang, J. Am. Chem. Soc., 2010, 132, 14; (b) F. Xiao, J. Hao, J. Zhang, C. Lv, P. Yin, L. Wang and Y. Wei, J. Am. Chem. Soc., 2010, 132, 5956; (c) S. T. Zheng, J. Zhang and G. Y. Yang, Angew. Chem., Int. Ed., 2008, 47, 3909; (d) J. Zhang, J. Luo, P. Wang, B. Ding, Y. Huang, Z. Zhao, J. Zhang and Y. Wei, Inorg. Chem., 2015, 54, 2551.

15 (a) N. Micali, H. Engelkamp, P. G. van Rhee, P. C. M. Christianen, L. M. Scolaro and J. C. Maan, Nat. Chem., 2012, 4, 201; (b) S. T. Wu, Z. W. Cai, Q. Y. Ye, C. H. Weng, X. H. Huang, X. L. Hu, C. C. Huang and N. F. Zhuang, Angew. Chem., Int. Ed., 2014, 53, 12860; (c) P. C. Yin, Z. M. Zhang, H. J. Lv, T. Li, F. Haso, L. Hu, B. F. Zhang, J. Bacsa, Y. G. Wei, Y. Q. Gao, Y. Hou, Y. G. Li, C. L. Hill, E. B. Wang and T. B. Liu, Nat. Commun., 2015, 6475.

16 (a) T. Yamase, Polyoxometalates active against tumors, viruses, and bacteria. Biomedical Inorganic Polymers,
Progress in Molecular and Subcellular Biology, 2013, vol. 54, p. 65; (b) T. Yamase, J. Mater. Chem., 2005, 15, 4773; (c) J. T. Rhule, C. L. Hill and D. A. Judd, Chem. Rev., 1998, 98, 327.

17 (a) H. Yanagie, A. Ogata, S. Mitsui, T. Hisa, T. Yamase and M. Eriguchi, Biomed. Pharmacother., 2006, 60, 349; (b) A. Ogata, H. Yanagie, E. Ishikawa, Y. Morishita, S. Mitsui, A. Yamashita, K. Hasumi, S. Takamoto, T. Yamase and M. Eriguchi, Br. J. Cancer, 2008, 98, 399; (c) X. Wang, J. Liu, J. Li, Y. Yang, J. Liu, B. Li and M. T. Pope, J. Inorg. Biochem., 2003, 94, 279; (d) X. Wang, F. Li, S. Liu and M. T. Pope, J. Inorg. Biochem., 2005, 99, 452; (e) X. Liu, S. Wang and C. Feng, J. Rare Earths, 2010, 28, 965.

18 (a) A. Ogata, S. Mitsui, H. Yanagie, H. Kasano, T. Hisa, T. Yamase and M. Eriguchi, Biomed. Pharmacother., 2005, 59, 240; (b) S. Mitsui, A. Ogata, H. Yanagie, H. Kasano, T. Hisa, T. Yamase and M. Eriguchi, Biomed. Pharmacother., 2006, 60, 353; (c) H. Fujita, T. Fujita, T. Sakurai, T. Yamase and Y. Seto, Tohoku J. Exp. Med., 1992, 168, 421.

19 (a) M. Ibrahim, S. S. Mal, B. S. Bassil, A. Banerjee and U. Kortz, Inorg. Chem., 2011, 50, 956; (b) A. Dolbecq, J. D. Compain, P. Mialane, J. Marrot, E. Rivière and F. Sécheresse, Inorg. Chem., 2008, 47, 3371; (c) J. P. Wang, P. T. Ma, J. Li, H. Y. Niu and J. Y. Niu, Chem.-Asian J., 2008, 3, 822 .

20 J. Fischer, L. Ricard and R. Weiss, J. Am. Chem. Soc., 1976, 98, 3050 .

21 (a) C. Viedma, Phys. Rev. Lett., 2005, 94, 065504; (b) J. H. E. Cartwright, J. M. García-Ruiz, O. Piro, C. I. SainzDíaz and I. Tuval, Phys. Rev. Lett., 2004, 93, 035502; (c) D. K. Kondepudi, R. J. Kaufman and N. Singh, Science, 1990, 250, 975.

22 (a) L. J. Prins, J. Huskens, F. D. Jong, P. Timmerman and D. N. Reinhoudt, Nature, 1999, 398, 498; (b) L. R. MacGillivray and J. L. Atwood, Nature, 1997, 389, 469. 23 (a) Y. J. Shi, H. Y. Liu, M. Xu, Z. P. Li, G. Q. Xie, L. Huang and Z. Z. Zeng, Spectrochim. Acta, Part A, 2012, 87, 251; (b) Y. R. Cui, E. Hao, G. Q. Hui, W. Guo and F. L. Cui, Spectrochim. Acta, Part A, 2013, 110, 92; (c) Y. J. Hu, H. L. Yue, X. L. Li, S. S. Zhang, E. Tang and L. P. Zhang, J. Photochem. Photobiol., B, 2012, 112, 16.

24 (a) A. Sulkowska, J. Mol. Struct., 2002, 614, 227; (b) Y. Ni, G. Liu and S. Kokot, Anal. Lett., 2009, 42, 206.

25 (a) J. R. Lakowicz, Principles of fluorescence spectroscopy, Springer Press, New York, 3rd edn, 2006; $(b)$ B. K. Paul and N. Guchhait, Photochem. Photobiol. Sci., 2011, 10, 980.

26 G. M. Sheldrick, SHELXL97, Program for Crystal Structure Refinement, University of Göttingen, Göttingen, Germany, 1997; G. M. Sheldrick, SHELXS97, Program for Crystal Structure Solution, University of Göttingen, Göttingen, Germany, 1997. 